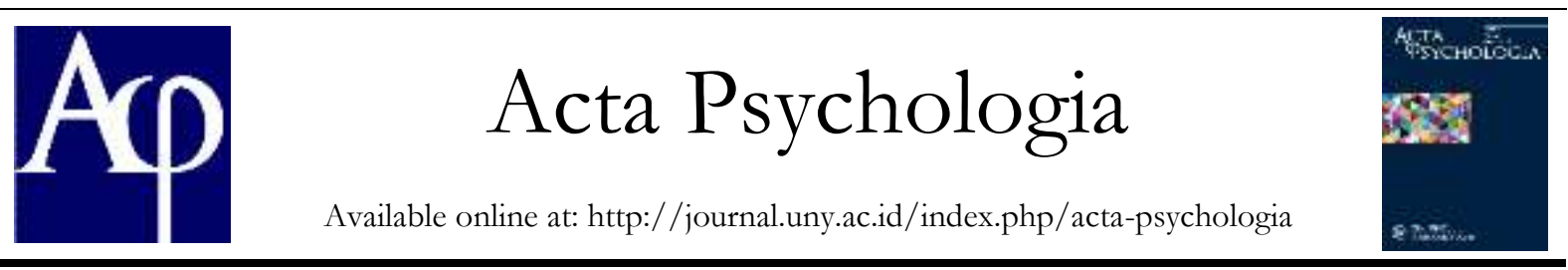

\title{
Pengaruh Resiliensi terhadap Harga Diri Remaja di Panti Asuhan Yatim dan Tunanetra Muhammadiyah Purworejo
}

\author{
Catur Widi Wasono \\ Jurusan Psikologi, Fakultas Ilmu Pendidikan; Universitas Negeri Yogyakarta; \\ Jl. Colombo No. 1 Sleman Yogyakarta, 55281 \\ caturwdwasono@gmail.com
}

\begin{abstract}
Abstrak
Penelitian ini bertujuan untuk: (1) mengetahui resiliensi remaja di panti asuhan, (2) mengetahui harga diri remaja di panti asuhan, (3) mengetahui pengaruh resiliensi terhadap harga diri remaja di Panti Asuhan Yatim dan Tunanetra Muhammadiyah Purworejo. Jenis penelitian ini adalah ex-post facto. Sampel dalam penelitian ini sejumlah 44 remaja di panti asuhan. Skala resiliensi $(\alpha=0.699, \mathrm{p}<0.001)$ dan skala harga diri $(\alpha=0.741, \mathrm{p}<0.001)$ digunakan sebagain instrumen untuk mengumpulkan data. Data dianalisis menggunakan analisis deskriptif dan uji regresi sederhana. Hasil penelitian menunjukkan: (1) Resiliensi pada remaja di Panti Asuhan Yatim dan Tunanetra Muhammadiyah Purworejo mayoritas berada pada kategori sedang; (2) Harga diri pada remaja di Panti Asuhan Yatim dan Tunanetra Muhammadiyah Purworejo mayoritas berada pada kategori tinggi; (3) Ada pengaruh variabel resiliensi terhadap harga diri dengan nilai $\mathrm{R}^{2}=0.332 \mathrm{~F}(1,43)=20.84, \mathrm{p}<0.001$. Dengan demikian, variabel resiliensi dapat mempengaruhi harga diri pada remaja yang tinggal di panti asuhan sebesar $33.2 \%$.
\end{abstract}

Kata Kunci: reseliensi, harga diri, remaja

\begin{abstract}
The purposes of this study were to: (1) determine the resilience level of adolescents in orphanage, (2) determine adolescents' the self-esteem in orphanages (3) determine the effect of resilience on adolescent self-esteem in Muhammadiyah Purworejo Orphanage for orphans and blind. This study were ex-post facto research. The subjects participated in this research were 44 teenagers in the orphanage. Resilience scale $(\alpha=0,699, \mathrm{p}<0,001)$ and selfesteem scale $(\alpha=0.741, \mathrm{p}<0.001)$ were used as the instruments for collecting the data. Data were analyzed using descriptive analysis and simple regression analysis. The results indicated that: (1) The adolescents resilience in Muhammadiyah Purworejo orphanage for orphans and blind are mostly in moderate or sufficient category; (2) The adolescents self-esteem of in Muhammadiyah Purworejo orphanage for orphans and blind is mostly in high category; (3) Self-esteem is affected by resilience variable with a value of $\mathrm{R}^{2}=0.332, \mathrm{~F}(1,43)=20.84, \mathrm{p}<0.001$. Thus, the resilience can affect self-esteem in adolescent who lives in orphanage by $33.2 \%$.
\end{abstract}

Keywords: resilience, self-esteem, adolescent

\section{Pendahuluan}

Remaja merupakan masa transisi dari anakanak menuju dewasa, dimana pada masa ini mereka banyak mengalami perubahan. Menurut Papalia dan Olds (dalam Tjahja, 2011) masa remaja adalah masa transisi perkembangan antara masa kanak-kanak dan dewasa yang pada umumnya dimulai pada usia 12 atau 13 tahun dan berakhir pada usia akhir belasan tahun atau awal dua puluh tahun. Anna Freud (dalam Tjahja, 2011) berpendapat bahwa pada masa remaja akan terjadi proses perkembangan meliputi perubahanperubahan yang berhubungan dengan perkembangan psikoseksual, dan juga terjadi perubahan dalam hubungan dengan orangtua dan cita-cita mereka, di mana pembentukan cita-cita merupakan proses pembentukan orientasi masa depan tentang apa dan bagaimana masa depan remaja tersebut. Untuk mencapai beberapa hal tersebut, remaja perlu melakukannya dengan baik sesuai tugas perkembangannya pada usia remaja. 
Menurut Richmond dan Sklansky (dalam Sarwono, 2012) tugas perkembangan dalam periode remaja awal dan menengah adalah memperjuangkan kebebasan. Tugas perkembangan ini menjadi sangat penting, dimana pada prosesnya akan menghasilkan bagaimana remaja tersebut berperilaku dalam masyarakat. Tetapi untuk melakukan tugas perkembangan tersebut, tentu remaja perlu dukungan dari orang-orang di sekitarnya, khususnya keluarga. Gauvin dan Parke (dalam Santrock, 2012), menyatakan bahwa pengawasan, pengertian dan dukungan dari orang tua, sangat bermanfaat bagi perkembangan remaja.

Peran keluarga khususnya orang tua sangatlah penting dalam melewati masamasa remaja dalam pembentukan kepribadiannya. Al-Jauhari dan Khayyal (2005) mengatakan bahwa orang tua perlu memahami bagaimana mendidik anak dan mengawasi, membimbing sesuai tahapan yang baik, dan dimulai dari tahap yang paling penting. McCartney (2007), menyatakan bahwa kualitas pengasuhan orang tua adalah faktor kunci perkembangan anak. Perasaan aman, dan kasih sayang yang diterima dari keluarga dapat membawa pada terbentuknya pribadi yang baik pada remaja. Perasaan aman dan terlindungi memungkinkan adanya suatu perkembangan yang baik bagi remaja agar menjadi seseorang yang matang.

Berdasarkan fakta di lapangan, tidak semua remaja memiliki orang tua, dimana hal ini menjadikan mereka melewati tugas perkembangan tanpa didampingi orang tua mereka. Banyak remaja yang harus berpisah denagn orangtua karena berbagai alasan atau peristiwa tertentu sehingga mereka harus menjalani hidup tanpa kehadiran orang tua kandung mereka. Berdasarkan penelitian yang dilakukan Save the Children dan Kementerian Sosial (Kemensos) dengan dukungan dari UNICEF pada tahun 2006-2007 diperoleh informasi banyak anak-anak ditempatkan di panti asuhan oleh keluarganya yang mengalami kesulitan ekonomi dan juga secara sosial dalam konteks tertentu, dengan tujuan untuk memastikan anak-anak mereka mendapatkan pendidikan. Berdasarkan hasil penelitian mengenai data di suatu panti asuhan, banyak faktor yang membuat anakanak dan remaja yang tinggal menetap di panti asuhan. Penelitian sebelumnya di Indonesia yang dilakukan oleh organisasi kemanusiaan Save of Children dengan UNICEF pada 2009 menemukan sekitar $6 \%$ dari lima ratus ribu anak berada dalam pengasuhan rumah yatim piatu adalah anak yang benar-benar yatim piatu, 94\% menjadi penghuni panti karena alasan kemiskinan, orang tua tidak mampu untuk menafkahi dengan layak sehingga anak- anak mereka dititipkan di rumah pengasuhan yatim piatu (Yuniana, 2012).

Panti asuhan adalah lembaga yang berperan sebagai pengganti keluarga dalam memenuhi kebutuhan anak dalam proses perkembangannya. Menurut Poerwadarminta (1995), panti asuhan adalah tempat untuk memelihara dan merawat anak yatim, piatu dan yatim piatu. Setiap orang yang tinggal di panti asuhan memiliki hak yang sama, yaitu mendapatkan kasih sayang, perhatian, dan cinta. Mereka membutuhkan figur keluarga yang dapat memberikan mereka rasa aman, bimbingan dan dukungan, sehingga mereka dapat menerima diri dan dapat menunjukkan potensi-potensi yang ada dalam diri. Standar

Pelayanan sosial anak jalanan melalui rumah singgah (2002), menyatakan bahwa Panti Asuhan adalah suatu lembaga pelayanan profesional yang bertanggung jawab memberian pengasuhan dan pelayanan pengganti fungsi orang tua kepada anak.

Di panti asuhan, berbagai peran yang orang tua lakukan untuk anaknya digantikan oleh pengasuh. Pengasuh memiliki peran penting untuk mengurus, memberi kasih sayang, perhatian, dukungan, dan perawatan. Agus Sunarto (Aini, 1993), mengatakan bahwa tugas dan kewajiban tenaga pengasuh sebagai berikut: 
"Bertanggung jawab terhadap pemenuhan kebutuhan fisik, mental spritual, sosial bagi anak-anak, memahami masalah- masalah yang dialami anak asuh dan berusaha memberikan bantuan pemecahannya dengan rnenggunakan sumber-sumber yang tersedia baik di dalam maupun di luar panti asuhan, mampu menggunakan semaksimal mungkin segala fasilitas yang diterimanya sebagai keluarga asuh untuk peningkatan pelayanan anak asuh melaksanakan berbagai jenis pencatatan yang berhubungan dengan proses pelayanan anak asuh, ikut aktif dalam kegiatan-kegiatan rutin maupun insidental, baik di dalam maupun di luar panti asuhan yang berhubungan dengan pelayanan anak asuh mengatur kehidupan keluarga sedemikian rupa sehingga anak asuh merasa aman dan tentram didalam tanggungjawab asuhannya.

Pada kenyataannya, hal-hal seperti perhatian, bimbingan, dukungan, dan kasih sayang yang tidak bisa tercurahkan pada satu anak saja, sangat memungkinkan bahwa anak- anak merasa kurang mendapatkan perhatian, dukungan dan kasih sayang. Ada beberapa remaja yang tinggal di panti asuhan menutup diri, merasa rendah diri sehingga menjadi pemalu dalam bergaul karena pengasuhan yang mereka dapatkan tidak sama kualitasnya seperti pengasuhan yang berasal dari orang tua kandung. Hal ini sesuai dengan wawancara yang dilakukan dengan penghuni Panti Asuhan Keluarga Yatim Muhammadiyah Surakarta. Di panti tersebut ada beberapa anak panti yang mengalami berbagai macam masalah yang merupakan manifestasi dari emosi negatif, diantaranya adalah anak panti merasa pengasuh di panti asuhan kurang perhatian sehingga menimbulkan ketidaknyamanan. Jika memiliki masalah, mereka cenderung menyimpan masalahnya sendiri serta merasa sedih apabila mengingat keberadaan orang tua dan keluarga yang jauh (Aisha, 2014).

Hal tersebut dapat mempengaruhi perkembangan mental yang mengakibatkan kurangnya harga diri dan juga dapat mengakibatkan depresi, stress dan berbagai gangguan emosi lainnya. Dalam penelitian Furnamawanti (2007) ditemukan bahwa sebagian besar anak-anak yang tinggal di panti asuhan memiliki tingkat kecenderungan depresi yang sedang dan tinggi dengan perolehan persentase 49,107\% dan 37,5\%. Wahyudiyanta (2011) mengungkapkan bahwa dari 27 korban meninggal akibat percobaan bunuh diri pada tahun 2007, lima diantaranya adalah penghuni panti asuhan.

Ada beberapa anak panti yang mendapat perlakuan tidak menyenangkan dari lingkungan sekitar. Berdasarkan penelitian yang dilakukan oleh Resty (2015) di Panti Asuhan Yatim Putri Aisyiyah Yogyakarta ada sebagian dari mereka yang mengaku pernah mendapat perlakuan negatif seperti ejekan dari teman karena latar belakang mereka yang tinggal di panti asuhan. Pengurus panti juga mengaku bahwa di lingkungan masyarakat terkadang masih memandang sebelah mata pada anakanak, salah satunya yaitu ejekan- ejekan yang dilakukan oleh teman sebaya dan lingkungan sekitar dapat menciptakan persepsi yang kurang baik bagi remaja di Panti Asuhan Yatim Putri Aisyiyah Yogyakarta. Bagi remaja Panti Asuhan Yatim Aisyiyah Yogyakarta yang tidak mampu menilai dirinya dengan baik akan memiliki harga diri yang rendah sehingga mereka tidak mampu bertahan untuk mengatasi setiap permasalahan yang di alami, karena sebagian besar harga diri berasal dari reaksi terhadap pendapat orangorang di sekitar tentang bagaimana cara orang lain bersikap dan bertindak.

Orang yang memiliki harga diri yang tinggi akan menilai dirinya secara positif. Menurut Rosenberg (dalam Mualfiah \& Indrijati, 2014), harga diri adalah sikap yang dimiliki tentang dirinya sendiri, baik positif maupun negatif. Menurut Coopersmith (dalam Ekasari \& Andriyani, 2013) harga diri merupakan penilaian diri yang dilakukan oleh seorang individu dan biasanya berkaitan dengan dirinya 
sendiri, penilaian tersebut mencerminkan sikap penerimaan atau penolakan dan menunjukkan seberapa jauh individu percaya bahwa dirinyamampu, penting, berhasil dan berharga.

Mereka mampu menerima dan mengenal diri sendiri dengan keterbatasannya. Schultz (1991) juga menjelaskan bahwa untuk memiliki perasaan harga diri yang sejati, individu harus mengetahui diri dengan baik dan mampu menilai secara objektif kebaikan dan kelemahan dirinya akan sesuatu yang dihadapi. Tinggi dan rendahnya harga diri seseorang tergantung dari penilaian orang di sekitar dan penilaian dari diri sendiri. Baron dan Byrne (2012) berpendapat bahwa harga diri adalah evaluasi diri yang dibuat oleh setiap individu, sikap orang terhadap dirinya sendiri dalam rentang dimensi positif sampai negatif. Crocker dan Cornie Wolfe (dalam Myers, 2012) menyatakan bahwa harga diri muncul ketika kita merasa

senang dengan domain (penampilan, kepandaian, dan lainnya) yang kita anggap penting bagi harga diri kita sendiri. Perkembangan harga diri pada seorang remaja akan menentukan keberhasilan maupun kegagalannya dimasa mendatang (Kamila \& Mukhlis, 2013).

Rendahnya harga diri remaja dapat disebabkan oleh pengaruh lingkungan yang mengucilkan dan tidak menghargai. Hasil penelitian yang dilakukan Mark Leary (dalamMyers, 2012) menyatakan bahwa penolakan sosial memperendah harga diri kita dan membuat kita semakin berusaha mendapatkan persetujuan, saat ditolak kita merasa tidak menarik. Penelitian yang dilakukan Mukhlis (2011) menyimpulkan bahwa harga diri yang rendah terbentuk ketika seseorang seringkali mendapat ejekan, hukuman, larangan yang berlebihan dan peritah yang tidak sewajarnya. Tingginya harga diri lebih disebabkan kontribusi orang tua terhadap kebutuhan anak. Coopersmith (dalam Santrock, 2007) menyimpulkan bahwa artibusi dari orang tua menyebabkan tingginya harga diri, seperti menunjukkan perhatian, ekspresi afeksi, membuat peraturan yang jelas dan adil, dan memberikan kebebasan pada anak dalam ranah yang baik. Tingginya harga diri seseorang berhubungan dengan kemampuan seseorang menghadapi atau beradaptasi terhadap tantangan dan tekanan hidup. Margareth (2016) menyebutkan bahwa harga diri berhubungan dengan resiliensi.

Remaja yang memiliki resiliensi yang tinggi merupakan seseorang yang mampu menghadapi kesulitan-kesulitan dalam hidupnya, serta dapat mengatasinya dengan lebih baik. Connor dan Davidson (dalam Roellyana \& Listiyandini, 2016) mengatakan bahwa resiliensi merupakan kualitas personal seseorang dalam hal kemampuan untuk menghadapi penderitaan. Sagor (Patilima, 2015) mendefinisikan resiliensi sebagai kumpulan atribut yang ada pada seorang individu dengan kekuatan dan ketabahan untuk menghadapi masalah besar yang mengikat kehidupannya. Remaja yang memiliki resiliensi yang baik, akan mampu melihat secara obyektif bagaimana dirinya akan bertahan dalam masalah yang dihadapi. Reivich dan Shatte (dalam Smith, 2013) menjelaskan bahwa resiliensi ialah kemampuan untuk merespon secara sehat dan produktif ketika berhadapan dengan kesengsaraan atau trauma, yang diperlukan untuk mengelola tekanan hidup sehari-hari.

Remaja di panti asuhan kadang terbuka dan tertutup pada orang lain. Mereka kadang-kadang dapat terbuka dengan orang lain dan dapat tertutup pada situasi tertentu. Hal ini diperkuat oleh hasil penelitian yang dilakukan Nisa dan Muis (2016) bahwa anak di panti asuhan sidoarjo menunjukkan resiliensi mayoritas pada kategori sedang dengan kriteria bahwa mereka netral, dimana pada situasi tertentu mereka dapat terbuka dan tertutup terhadap orang lain. Remaja yang memiliki resiliensi dapat diartikan sebagai individu yang dapat bangkit dari berbagai masalah yang dialaminya dalam pergaulan dengan lingkungan sekitarnya. 
Kompetensi personal, percaya pada diri sendiri, menerima perubahan secara positif, pengendalian diri, dan ambisi masa depan yang dimiliki seseorang akan mampu membentuk resiliensi seseorang. Schoon (dalam Patilima, 2015) mengidentifikasi bahwa individu yang mampu membangun resiliensi adalah individu yang mengenal kompetensinya, mampu merumuskan ambisi, aspirasi, rencana hidup yang jelas dan adaptasi positif. Oleh karena itu, remaja panti asuhan yang memiliki resiliensi yang baik kemungkinan juga memiliki harga diri yang tinggi terhadap dirinya sendiri. Salah satu syarat meningkatkan harga diri yaitu seseorang berani untuk menghadapi masalah yang dialaminya terlebih dahulu. Lazarus (dalam Santrock, 2007) mengatakan bahwa meningkatnya harga diri apabila remaja mencoba mengatasi suatu masalah yang dihadapi dan bukan menghindarinya. Resiliensi merupakan suatu hal yang penting untuk diteliti karena pengembangan resiliensi dapat meningkatkan kerentanan terhadap trauma dan berguna pada masa perkembangan selanjutnya (Clauss- Ehlers, dkk, 2008).

Berdasarkan penjelasan diatas, dapat diketahui bahwa masih ada beberapa remaja di panti asuhan yang mendapat perlakuan tidak menyenangkan dari lingkungan sekitar. Oleh karena itu, penting untuk mengetahui bagaimana perkembangan remaja dipanti asuhan, terutama terkait dengan harga diri dan resiliensi.

Panti Asuhan Yatim dan Tunanetra Muhammadiyah Purworejo merupakan panti asuhan yang mengedepankan nilai agama dalam kegiatannya. Penghuni panti asuhan merupakan anak-anak dan remaja. Panti Asuhan tersebut dipilih dikarenakan berdasarkan wawancara yang sudah dilakukan, remaja di Panti Asuhan sesuai dengan yang dibutuhkan yaitu remaja dengan usia 13 tahun sampai 18 tahun, selain itu remaja di Panti Asuhan tersebut mayoritas berasal dari keluarga yang bermasalah seperti perceraian orang tua, pendapatan orang tua yang rendah dan tidak adanya kedua orang tua mereka. Dua alasan tersebut tidak dimiliki sekaligus Panti Asuhan yang lain di Yogyakarta dan Purworejo.

Berdasarkan permasalahan yang ada, peneliti tertarik untuk melakukan penelitian tentang pengaruh resiliensi terhadap harga diri pada remaja di Panti Asuhan Yatim dan Tunanetra Muhammadiyah Purworejo.

\section{Metode Penelitian}

\section{Jenis Penelitian}

Penelitian ini menggunakan pendekatan kuantitaif dengan jenis ex post facto.

\section{Waktu dan Tempat Penelitian}

Penelitian ini dilaksanakan di Panti Asuhan Yatim dan Tunanetra Muhammadiyah Purworejo. Pemilihan lokasi ini berdasarkan hasil prasurvei di beberapa panti asuhan di daerah Yogyakarta dan Purworejo termasuk Panti Asuhan Yatim dan Tunanetra Muhammadiyah Purworejo dan peneliti memilih masalah yang berkaitan dengan harga diri yang rendah pada remaja Panti Asuhan yang disinyalir dialami Remaja Panti Asuhan, maka peneliti memilih Panti Asuhan Yatim dan Tunanetra Muhammadiyah Purworejo sebagai lokasi untuk penelitian ini. Selain itu, belum ada penelitian terkait dengan variabel-variabel dalam penelitian ini yang dilakukan di sebuah Panti Asuhan. Penelitian ini dilakukan pada 4 September 2018 - 2 Januari 2019 dan pengambilan data dilakukan pada tanggal 17 Oktober 2018 25 November 2018.

\section{Target/Subjek Penelitian}

Populasi adalah keseluruhan subjek yang akan dilakukan pengamatan dan penyedia data untuk penelitian. Sugiyono (2012) menyatakan bahwa populasi merupakan wilayah generalisasi (obyek/subyek) yang memiliki kualitas dan karakteristik yang ditetapkan oleh peneliti untuk dipelajari dan ditarik kesimpulan. Populasi pada penelitian ini adalah remaja di 
Panti Asuhan Yatim dan Tunanetra Muhammadiyah Purworejo yang berusia 12- 18 tahun, dengan jumlah populasi 50 remaja.

Pada penelitian ini, cara menentukan jumlah sampel dengan menggunakan adalah rumus Slovin. Adapun penelitian ini menggunakan rumus slovin karena dalam penarikan sampel, jumlahnya harus representative agar hasil penelitian dapat digeneralisasikan dan perhitungannya pun tidak memerlukan tabel jumlah sampel, namun dapat dilakukan dengan rumus dan perhitungan sederhana. Dari rumus slovin menghasilkan sampel berjumlah 44 remaja, rumus Slovin sebagai berikut : $\mathrm{n}=\mathrm{N} /(1+$ $\left(\mathrm{N} x \mathrm{e}^{2}\right)$ ). Pada penelitian ini, sebanyak 50 remaja, diberikan kesempatan untuk menjadi bagian dari sampel dan dihasilkan 44 remaja yang ditetapkan sebagai sampel.

\section{Prosedur}

Cara pengambilan sampel pada penelitian ini menggunakan teknik simple random sampling. Menurut Sugiyono (2012) teknik simple random sampling adalah sampling yang memberikan peluang yang sama bagi setiap anggota yang dipilih menjadi anggota sampel. Pada penelitian ini, pengambilan sampel diawali dengan pengumpulan 50 remaja dan selanjutnya dipilih 44 remaja secara acak untuk dijadikan sampel.

\section{Instrumen}

Alat ukur pada penelitian ini menggunakan skala Likert. Menurut Sugiyono (2012) skala Likert merupakan skala yang digunakan untuk mengukur sikap, pendapat, dan presepsi seseorang atau sekelompok orang tentang fenomena sosial atau gejala sosial. Pada skala Likert variabel yang akan diukur dan dijabarkan menjadi indikator variabal yang kemudian dijadikan sebagai pedoman untuk menyusun item-item instrumen. Penelitian ini menggunakan skala psikologis dengan skala Likert yang dimodifikasi menjadi 4 alternatif jawaban yaitu sangat sesuai (ss), sesuai (s), kurang sesuai (ks), sangat kurang sesuai (sks) dengan menghilangkan jawaban ragu-ragu karena orang cenderung akan memilih jawaban ragu- ragu dan cenderung tidak akan menjawab sesuai atau tidak sesuai pada pernyataan dalam skala.

Penelitian ini menggunakan skala resiliensi dan skala harga diri. Skala resiliensi disusun berdasarakan aspek-aspek yang dikemukakan Reivich dan Shatte (dalam Azzahra, 2017) yang terdiri dari regulasi emosi, kontrol impuls, optimisme, analsis penyebab, empati, efikasi diri, dan reaching out. Skala harga diri disusun berdasarkan aspek harga diri yang dikemukakan oleh Coopersmith (1967), yang terdiri dari power (kekuatan), significance (keberartian), virtue (kebajikan), competence (kemampuan). Skala harga diri pada penelitian ini memodifikasi skala harga diri dari Coopersmith.

\section{Teknik Analisis Data}

Analisis data dilakukan sebelum dan setelah pengumpulan data yang sudah dianalisis dengan baik dan sesuai rumusan masalah.

1. Analisis Deskriptif

Data yang berupa angket resiliensi diperolah dari kategori yang terdiri dari pilihan yang tinggi $(4)=$ sangat sesuai $=$ sangat tinggi, $(3)=$ sesuai $=$ tinggi, $(2)=$ tidak sesuai $=$ rendah, $(1)=$ sangat tidak sesuai $=$ sangat rendah. Kategori dari sangat tinggi sampai sangat rendah akan diubah dalam data interval. Azwar (2007) membagi interval variabel resiliensi dan harga diri yang dapat dilihat menggunakan rumus:

$$
\begin{array}{ll}
\text { Tinggi } & : \mathrm{X} \geq \mathrm{M}+\mathrm{SD} \\
\text { Sedang } & : \mathrm{M}-\mathrm{SD} \leq \mathrm{X}<\mathrm{M}+\mathrm{SD} \\
\text { Rendah } & : \mathrm{X}<\mathrm{M}-\mathrm{SD}
\end{array}
$$

2. Uji Normalitas

Uji normalitas digunakan untuk mengetahui data dalam penelitian berdistribusi normal atau tidak. Uji normalitas ini digunakan untuk melakukan pengujian normalitas sampel (Juliansyah, 2011). Penelitian ini menggunakan uji normalitas Shapiro-Wilk dengan bantuan IBM SPSS Statistics 22. Pengujian ini 
dilakukan pada nilai residual dari $\mathrm{Y}$, yakni selisih dari $\mathrm{Y}$ yang merupakan hasil pengamatan dan $\mathrm{Y}$ prediksi yang berdasarkan persamaan regresi.

\section{Hasil Penelitian dan Pembahasan}

\section{Resiliensi}

Di Panti Asuhan Yatim dan Tunanetra Muhammadiyah Purworejo Putri Yogyakarta terdapat 17 orang memiliki resiliensi yang tinggi, 26 orang memiliki resiliensi yang sedang dan satu orang dengan resiliensi rendah. Dengan demikian dapat disimpulkan bahwa resiliensi remaja di Panti Asuahan Yatim dan Tunanetra Muhammadiyah Purworejo berada pada kategori sedang. Sebaran data pada masingmasing kategori disajikan dalam grafik, pada gambar dibawah ini.

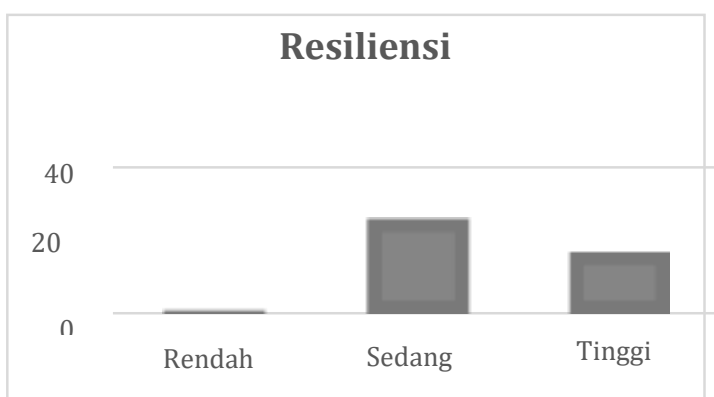

Gambar 1. Diagram Distribusi Frekuensi Kategorisasi Resiliensi.

\section{Harga Diri}

Skor kategorisasi harga diri remaja di Panti Asuhan Yatim dan Tunanetra Muhammadiyah Purworejo Putri Yogyakarta terdapat 30 orang memiliki harga diri yang tinggi, 14 orang memiliki harga diri yang sedang dan tidak ada yang rendah. Dengan demikian dapat disimpulkan bahwa harga diri remaja di Panti Asuahan Yatim dan Tunanetra Muhammadiyah Purworejo berada pada kategori tinggi. Sebaran data pada masingmasing kategori disajikan dalam grafik, pada gambar dibawah ini.

Gambar 2. Diagram Distribusi Frekuensi Kategorisasi Harga Diri

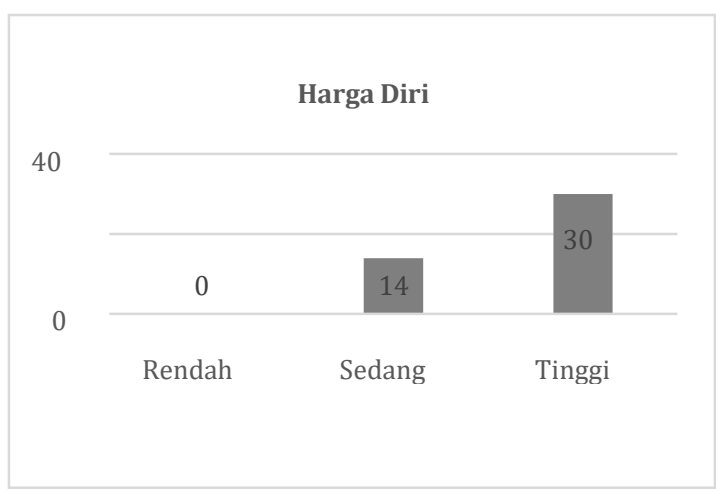

\section{Uji Normalitas}

Uji normalitas pada penelitian ini menggunakan uji Shapiro Wilk melalui program IBM SPSS Statistic 22. Berdasarkan perhitungan, diperoleh hasil bahwa Asymp. Sig (2- tailed) yang diperoleh yaitu $p>0.05$ yang berarti distribusi skornya dikatakan normal. Dengan demikian, berdasarkan grafik histogram dan nilai signifikansi, maka dapat disimpulkan bahwa data yang ada memenuhi asumsi normalitas.

Tabel 1. Hasil Uji Normalitas Residual

\begin{tabular}{llll}
\hline \multicolumn{4}{c}{ Shapiro Wilk } \\
\hline Variabel & Statistic & Df & Sig. \\
\hline $\begin{array}{l}\text { Unstandardiz } \\
\text { ed Residual }\end{array}$ & .964 & 44 & .187 \\
\hline
\end{tabular}

\section{Uji Linearitas}

Uji linieritas digunakan untuk mengetahui apakah variabel bebas dengan variabel terikat memiliki hubungan linear atau tidak. Dua variable dikatakan linear apabila nilai signifikansi >0.05. Penghitungan uji linieritas pada penelitian ini menggunakan IBM SPSS Statistic 22. Berdasarkan perhitungan, diperoleh nilai sigifikansi $\mathrm{F}$ untuk variabel resiliensi dengan variabel harga diri adalah 0.529 yang berarti bahwa $0.529>0.05$ atau $\mathrm{p}>0.05$, sehingga kedua variabel pada penelitian ini memiliki hubungan yang linear.

\section{Uji Hipotesis}


Uji hipotesis dilakukan untuk menguji kebenaran dari jawaban sementara tersebut agar diperoleh kesimpulan. Hipotesis dalam penelitian ini adalah "ada pengaruh resiliensi terhadap harga diri remaja di Panti Asuhan Yatim dan Tunanetra Muhammadiyah Purworejo" Hipotesis dapat diterima apabila nilai signifikansi $<0.05$.

Tabel 2. Uji Hipotesis

\begin{tabular}{ccccccc}
\hline & \multicolumn{2}{c}{$\begin{array}{c}\text { Unstandardized } \\
\text { Coefficients }\end{array}$} & $\begin{array}{c}\text { Standardized } \\
\text { Coefficients }\end{array}$ & & \\
\cline { 2 - 5 } Model & $\mathbf{B}$ & Std. Error & Beta & T & Sig. \\
\hline (Constant) & 32.167 & 4.520 & & 7.117 & .000 \\
Resiliensi & .561 & .123 & .576 & 4.565 & .000 \\
\hline
\end{tabular}

Berdasarkan hasil analisis data pada tabel di atas perhitungan antara penerimaan diri dan harga diri diperoleh nilai konstanta sebesar 32. 167 dan nilai koefisien regresi prediktor sebesar 0.576 dan nilai thitung sebesar 4.565 dengan nilai sigifikansi (p) sebesar $0.001<$ 0.05 yang membuktikan bahwa terdapat pengaruh antara resiliensi terhadap harga diri. Dengan demikian hipotesis yang berbunyi "ada pengaruh resiliensi terhadap harga diri remaja di Panti Asuhan Yatim dan Tunanetra Muhammadiyah Purworejo" diterima. Hal ini dapat diartikan pula bahwa resiliensi memprediksi harga diri.

Selain itu terdapat pula sumbangan untuk variabel bebas (resiliensi) untuk variable terikat (harga diri) yang dapat dilihat pada tabel 3 .

Tabel 3. Sumbangan Resiliensi Terhadap Harga Diri

\begin{tabular}{ccccc}
\hline Model & $\mathbf{R}$ & $\begin{array}{c}\mathbf{R} \\
\text { Square }\end{array}$ & $\begin{array}{c}\text { Adjusted } \\
\text { R Square }\end{array}$ & $\begin{array}{c}\text { Std. Error } \\
\text { of the } \\
\text { Estimate }\end{array}$ \\
\hline 1 & .576 & .332 & .316 & 4.47213 \\
\hline
\end{tabular}

Dapat dilihat pada Tabel 3 , bahwa koefisien determinasi Rsquare penerimaan diri terhadap harga diri sebesar 0,332 atau 33\% yang berarti bahwa sumbangan efektif variable penerimaan diri terhadap harga diri sebesar 33\%, dan 67\% dipengaruhi faktor lain yang tidak diteliti pada penelitian ini.

\section{Pembahasan}

Pada penelitian dihasilkan bahwa ada pengaruh positif resiliensi terhadap harga diri. Seseorang yang memiliki resiliensi tinggi akan mampu untuk bangkit, menghadapi masalah yang dihadapi di Panti Asuhan, mereka bisa mengatur emosi, mengetahui penyebab dari masalah yang dihadapi, berani menghadapi masalah yang dialami, memiliki keyakinan bahwa masalah yang dihadapi akan selesai, dapat menempatkan diri di posisi orang lain, dapat mengontrol perilakunya dengan baik, dan mampu untuk memetik hal positif dari pengalaman yang buruk. Hal ini diperkuat dengan hasil penelitian yang dilakukan Reivich dan Shatte (dalam Prihastuti, 2011) yang menyimpulkan bahwa resiliensi yang tinggi meliputi kemampuan mengatur emosi, berhubungan baik dengan orang lain, kontrol diri, optimis, empati, analsis masalah, dan efikasi diri.

Seseorang yang memiliki resiliensi sedang, mereka juga mampu mengendalikan emosi, mampu untuk optimis dan mampu menyelesaikan masalah dengan tenang, membuka diri, dan mengendalikan keinginan diri dengan intensitas yang lebih rendah. Mereka dapat mengenadalikan emosi, berempati, optimis, mengendalikan diri, bersikap tenang pada saat tertentu dan tidak sesering seseorang dengan resiliensi tinggi. Hal ini diperkuat dari hasil penelitian yang dilakukan oleh Herdiana dan Riza (2013) bahwa resiliensi pada remaja binaan BAPAS yang berada pada taraf sedang menunjukkan kemampuan untuk mengendalikan emosi, optimis, dan cukup mampu menyelesaikan masalah dengan tenang. Adanya resiliensi pada remaja panti asuhan disebabkan karena adanya keaktifan subyek untuk mengikuti berbagai kegiatan yang mendukung terbentuknya resiliensi, seperti mengaji yang berguna meningkatkan kemampuan pengendalian emosi dan perilaku, dan ada acara AMT (Achievement Motivation Training) dari organisasi 
tertentu untuk mendorong semangat remaja panti asuhan. Selain itu, mereka yang tidak memiliki kekuatan untuk beradaptasi dengan kehidupan panti, mereka akan keluar dari panti asuhan. Berdasarkan wawancara yang dilakukan oleh peneliti di panti asuhan yatim dan tunanetra muhammadiyah purworejo, pernah ada remaja yang pulang ke rumah sendiri karena tidak tahan dengan kehidupan panti, dan ada pula yang dikembalikan ke walinya karena memberontak, sehingga menjadikan resiliensi remaja di Panti Asuhan yang kategori rendah hanya satu orang.

Hasil penelitian ini menunjukkan bahwa dari 44 remaja di Panti Asuhan Yatim dan Tunanetra Muhammadiyah Purworejo Yogyakarta 30 orang memiliki harga diri yang tinggi dan 14 orang dengan harga diri sedang. Dengan demikian dapat disimpulkan bahwa harga diri Remaja di Panti Asuhan Yatim dan Tunanetra Muhammadiyah Purworejo mayoritas pada kategori tinggi. Tingkat harga diri remaja di Panti Asuhan Yatim dan Tunanetra Muhammadiyah Purworejo yang tinggi berarti mereka memiliki kepercayaan diri yang baik, dapat berapatasi dengan kehidupan sosialnya, aktif, berprestasi dan mampu bersikap tenang. Hal ini sejalan dengan pendapat Coopersmith (1967) yang menyatakan bahwa seseorang yang memiliki harga diri tinggi adalah mereka yang bersifat aktif dan agresif, dalam bidang akademis cender ung sukses dan juga dalam hubungan sosial. Dalam pergaulan lebih bersifat memimpin, bebas berpendapat, tidak menghindari perbedaan pendapat, tahan terhadap semua kritikan dan tidak mudah cemas.

Bagi remaja yang memiliki harga diri sedang, mereka mempunyai persamaan dengan individu yang mempunyai taraf harga diri tinggi. Perbedaannya hanya terletak pada intensitas keyakinan diri, mereka akan percaya diri, aktif pada saat tertentu saja. Besarnya masalah yang mereka alami berpengaruh terhadap tingkat kepercayaan diri mereka, dimana ketika masalahnya besar mereka cenderung tidak percaya diri dan jika masalahnya lebih kecil mereka dapat percaya diri, aktif dan menyesuaikan diri.

Tinggi dan sedangnya harga diri mereka disebabkan oleh adanya kegiatan seperti olahraga bersama yang dilakukan seluruh penghuni panti dan membuat mereka berpartisipasi untuk menunjukkan kemampuannya sehingga akan menaikkan harga diri mereka, selain itu ada kegiatan Panti yang bisa meningkatkan harga diri mereka, seperti pembuatan jamur untuk melatih mereka berwirausaha yang akan meningkatkan harga diri mereka. Aktivitas wirausaha dapat memunculkan keinginan untuk dapat menunjukkan kemampuan yang dimiliki, dapat mendorong sikap saling membantu, dimana hal tersebut merupakan komponen yang penting dalam pembentukan harga diri. Hasil penelitian yang dilakukan oleh Dewi dan Parnawa (2016) menunjukkan bahwa niat berwirausaha memiliki hubungan yang signifikan dengan harga diri.

Subjek penelitian ini adalah remaja perempuan yang berada pada rentang usia 12- 18 tahun, dimana pada usia tersebut mereka masih pada tahap pencarian jadi diri. Berdasarkan kajian tentang harga diri pada remaja, menurut Sullivan (Santrock, 2011:446) menyatakan bahwa perubahan sosial yang penting pada masa remaja salah satunya yaitu meningkatnya pengaruh teman sebaya, pola perilaku yang matang, pembuatan kelompok sosial yang baru, dan munculnya nilai-nilai baru dalam memilih teman dan pemimpin serta nilai dalam penerimaan sosial. Meninjau dari karakteristik tersebut maka relevan jika hasil penelitian ini menunjukkan bahwa harga diri remaja di Panti Asuhan Yatim dan Tunanetra Muhammadiyah Purworejo mayoritas pada kategori sedang, karena subjek dalam penelitian ini berada pada periode pencarian identitas diri.

Berdasarkan hasil penelitian yang sudah dilakukan dihasilkan bahwa terdapat pengaruh resiliensi terhadap harga diri pada 
remaja di Panti Asuhan Yatim dan Tunanetra Muhammadiyah Purworejo, dengan besaran pengaruh resiliensi terhadap harga diri ditunjukkan dengan uji $F$ dengan nilai signifikansi (p) $0,000<0,05$. Sumbangan efektif variabel resiliensi sebesar 33\% terhadap harga diri remaja di Panti Asuhan Yatim dan Tunanetra Muhammdiyah Purworejo, selebihnya dipengaruhi faktor lain sebesar $67 \%$, dimana faktor tersebut seperti penerimaan diri, faktor status sosial, ekonomi, dan prestasi belajar.

Resiliensi dapat mempengaruhi harga diri, dimana dengan resiliensi seseorang dapat bangkit ketika menghadapi masalah. Harga diri seseorang yang rendah karena tidak dihargai keberadaannya, dapat dibantu melalui resiliensi, dengan berusaha bangkit dari fakta yang membuatnya merasa dikucilkan seperti ketika seseorang dicap sebagai orang bodoh dikelas sehingga dikucilkan, ia berusaha bangkit dan menjadi rajin belajar sehingga nilainya naik dan lambat laun akan dianggap sebagai anak pandai. Hal ini sesuai dengan pendapat Reivich dan Shatte (dalam Fatimah, 2017) yang menjelaskan bahwa resiliensi ialah kemampuan untuk mengatasi suatu kejadian dan situasi yang berat atau masalah yang terjadi dalam sebuah kehidupan.

Dengan adanya resiliensi pada diri sendiri dapat menjadikan seseorang untuk bangkit pada situasai yang menekan, berat, dan tidak nyaman. Ketidaknyamanan yang dialami seseorang akan berhubungan dengan harga diri yang dimiliki orang tersebut. Oleh karena itu, seseorang membutuhkan resiliensi untuk mengatasi ketidaknyamanannya untuk membangkitkan harga diri orang yang bersangkutan.

Kemampuan seseorang dalam mengatur emosi, menunda keinginan, dan empati akan mempengaruhi perilaku seseorang dalam kehidupan sehari-hari. Selain itu, kemampuan untuk membuka diri atau pengambilan hikmah dari pengalaman masa lalu akan mempengaruhi seseorang dalam berbuat kebajikan dan kepercayaan diri. Meninjau dari komponen-komponen resiliensi yang mempengaruhi komponen harga diri tersebut maka dapat dikatakan bahwa resiliensi berpengaruh terhadap harga diri. Resiliensi akan berhubungan dengan harga diri sesuai dengan pendapat hasil penelitian Hidayati (2014) yang menyebutkan bahwa ada hubungan positif yang signifikan antara harga diri dengan resiliensi. Penelitian ini sejalan dengan penelitian yang pernah dilakukan sebelumnya oleh Resty (2017) yang dilakukan di SMPN 3 Cilacap terkait dengan pengaruh resiliensi terhadap harga diri siswa korban perceraian orang tua, dihasilkan bahwa terdapat pengaruh positif dan signifikan variabel resiliensi terhadap harga diri

\section{Simpulan dan Saran}

\section{Simpulan}

Berdasarkan penelitian yang sudah dilakukan dapat disimpulkan bahwa:

1. Resiliensi remaja di Panti Asuhan Yatim dan Tunanetra Muhammadiyah Purworejo sebagian besar berada pada kategori sedang atau cukup.

2. Harga diri remaja di Panti Asuhan Yatim dan Tunanetra Muhammadiyah Purworejo mayoritas pada kategori tinggi.

3. Terdapat pengaruh variabel resiliensi terhadap harga diri, dengan persamaan garis regresi $\mathrm{Y}=32.167+0.561 \mathrm{X}$ dan besarnya pengaruh resiliensi terhadap harga diri yaitu $33 \%$.

Saran

Berdasarkan kesimpulan dari penelitian yang sudah dilakukan, maka saran yang dapat diberikan sebagai berikut :

1. Bagi pengurus panti, resiliensi dan harga diri yang sudah ada di kategori tinggi pada remaja di Panti Asuhan Yatim dan Tunanetra Muhammadiyah Purworejo harus dipertahankan dengan mengikuti kegiatan yang 
berhubungan dengan resiliensi dan harga diri.

2. Bagi resiliensi dan harga diri yang masih dalam kategori sedang diusahakan untuk ditingkatkan. Dalam hal ini peran pengurus Panti diperlukan sebagai tenaga ahli yang bisa memberikan pelatihan di program keseharian panti terkait tentang resiliensi dan harga diri, untuk meningkatkan resiliensi dan harga diri.

3. Pengaruh resiliensi terhadap harga diri di penelitian ini 33\%. Oleh karena itu, diperlukan penelitian selanjutnya mengenai harga diri yang dapat dikaitkan dengan variabel lain yang mendukung harga diri seperti dukungan sosial, status ekonomi, penerimaan diri, dan lain sebagainya.

4. Bagi remaja di Panti Asuhan, berdasarkan hasil penelitian bahwa resiliensi dan harga diri yang mereka miliki dapat dijadikan bahan evaluasi dan instropeksi diri.

\section{Daftar Pustaka}

Anonim. ((2002)). Standar Pelayanan sosial anak jalanan melalui rumah singgah. 2002. Jakarta : Direktorat Bina Pelayanan Sosial Anak, Direktorat Jendral Pelayanan dan Rehabilitasi Sosial, Departemen Sosial RI.

Aini, W. (1993). Hambatan yang dialami pengasub dalam membimbing anak asub pada panti asuban mubammadiyah/aisiyah dalam daerah kotamadya padang. Pandang: IKIP Pandang.

Aisha, D.L. (2014) Hubungan Antara Religiusitas Dengan Resiliensi Pada Remaja Di Panti Asuhan Keluarga Yatim Muhammadiyah Surakarta. Skripsi (Tidak diterbitkan). Universitas Muhammadiyah Surakarta.

Al-Jauhari, M. \& Khayyal, M. (2005). Membangun keluarga qur'ani panduan untuk wanita muslimah. Jakarta: Amzah .

Azwar, S. (2015). Validitas dan reliabilitas ( Edisi 4). Yogyakarta: Pustaka Pelajar.

Azwar, S. (2007). Metode penelitian. Pustaka Pelajar: Yogyakarta.

Azzahra, F. (2017). Pengaruh resiliensi terhadap distres psikologis pada mahasiswa. Jurnal Ilmiah Psikologi Terapan, ISSN: 23018267 Vol.05,No.01. Diakses pada $24 \quad$ Oktober 2018. http://ejournal.umm.ac.id/inde x.php/ji pt/article/view/3883.

Burns, R.B. 1993. Konsep diri: Teori, pengukuran, perkembangan dan perilaku. (Alih Bahasa: Eddy). Jakarta: Arcan.

Byrne, D dan Robert A, B. (2002). Social psychology: Psikologi sosial (Edisi Kesepuluh). Alih Bahasa: Ratna Djuwita, Melania Meitty Parman, Dyah Yasmina, Lita P. Lunata. Jakarta: Erlangga.

Clauss-Ehler, C.S. (2008). Sosiocultural factors, resilience, and coping: Support for a culturally sensitive measure of resilience. Journal of Applied Developmental Psychology,29,197-212.

Connor, K. M., \& Davidson, J. R. T. (2003).Development of new resilience scale: the Connor Davidson resilience scale (CDRISC). Journal of Depression andAnxiety, Vol 18: 76-82. https://onlinelibrary.wiley.com/doi /epdf/10.1002/da.10113.

Coopersmith, S. (1967). The Antecedents of selfesteem. San Francisco: W.H. Freeman andCompany.

Darajat, Z. (2008). Metodik khusus pengajaran agama islam. Jakarta: Bumi Akasara. 
Dewi, G.K \& Henu, B. (2015). Resiliensi padaremaja yatim piatu yang tinggal di panti asuhan. Jurnal Spirits, Vol.5, No.2.

Dewi, N.L.P. (2016). Hubungan sikap kewirausahaan dengan niat kewirausahaan pada mahasiswa Universitas Atma Jaya Yogyakarta. Skripsi (Tidak diterbitkan). Universitas AtmaJaya Yogyakarta.

Ekasari, A. \& Andriyani, Z. (2013). Pengaruh peer group support dan self esteem terhadap resillience pada siswa SMAN Tambun Utara Bekasi. Jurnal Soul, Vol. 6No 1. 50-65.

Furnamawati. (2007). Kecenderungan depresi pada anak panti asuhan. Skripsi (Tidak diterbitkan). Malang: Fakultas Psikologi Universitas Muhammadiyah Malang.

Grotberg, E.H. (1995) 'The international resilience project: Research, application, and policy', international symposium on stress and violence, Lisbon, Portugal.

Herdiana, I. dan Muhammad, R. (2013). Resiliensi pada Narapidana Laki-laki di Lapas Klas I Medaeng. Jurnal Psikologi Kepribadian dan Sosial, 2/1: 1-6. Diakses pada tanggal 01 Januari 2019. http://www.journal.unair.ac.id/dow nloa jpksfbd660cc7a2full.pdf.

Hidayati, N. (2014). Hubungan antara self esteem dengan resiliensi pada remaja di panti asuhan keluarga yatim muhammadiyah surakarta. Skripsi (Tidak diterbitkan). Surakarta: Universitas Muhammadiyah Surakarta.

Izzaty, R.E, dkk. (2008). Perkembangan peserta didik. Yogyakarta: UNY Press.
Jahja, Y. (2011). Psikologi perkembangan. Jakarta: Kencana.

Jameel, S.N,. Shah S.S,. \& Ganaie, S.A. (2015).Perceived social support and resilience among orphans: a systematic review. The International Journal of Indian Psychology, 3, (1), 9

Hombrados, I \& Garcia, M. (2017).Resilience and personality in social work student and social workers. International Social Work 2017, Vol. 60(1) 19-31

Jefferis, T.C. \& Theron, L.C. (2017). Promoting resilience among sesotho- speaking adolescent girls: Lessons for South African teachers. South African Journal of Education, Vol. 37, No 3

Kamila, I. I. \& Mukhlis. (2013).Perbedaan harga diri (selfesteem) remaja ditinjau dari keberadaan ayah. Jurnal Psikologi, 9(2).

Katyal, S. (2015). A study of resilience in orphan and non-orphan children. International Journal of Multidisciplinary Research and Development . Volume: 2, Issue:7, 323-327.

Kemensos. (2011). Peraturan Menteri Sosial RI Nomor 30, Tahun 2011, tentang Standar Nasional Pengasuhan Anak Untuk Lembaga Kesejahteraan Sosial Anak.

Keye, M.D.\& Pidgeon, A.M. (2013). An investigation of the relationship between resilience, mindfulness, and academicself-efficacy. Open Journal of Social Sciences.1(6), 1 - 4.

Margareth, V. T. (2016). Hubungan selfesteem dengan resiliensi pada siswa Sekolah menengah pasca bencana banjir dan tanah longsor di daerah Batu Gajah Ambon. Skripsi (Tidak diterbitkan). Salatiga: Fakultas 
Psikologi Universitas Kristen Satya Wacana.

Masten, A. S. (2001). Ordinary magic: Resilience processes in development. American Psychologist, 56(3), 227-238.

McCartney, K. \& Phillips, P. (2006). Blackwell bandbook of early childhood development. Oxford: Blackwell Publishing.

Morgot, H. (1997). "Resilience and severe burns". Journal of Counseling and Development, Vol 75, 346-357.

Mualfiah, R. \& Indrijati, H. (2014). Hubungan antara tingkat harga diri dengankecenderungan perilaku seks pranikah pada remaja pondok pesantren assalafi alfitrah surabaya. Jurnal Psikologi Klinis dan Kesehatan Mental, Vol. 03 No. 03.

Myers, D.G. (2012). Psikologi sosial jilid 2. (Alih bahasa) Jakarta: Salemba Humanika.

Nisa, M.K. \& Muis, T. (2016). Studi tentangdaya tangguh (resiliensi) anak di panti asuhan sidoarjo. Universitas Negeri Surabaya.

Oktoviyani, R.N. \& Anggraeny, W. (2016). Penerimaan sistem e-learning menggunakan technology acceptance model (TAM) study kasus siswa/i kelas X di SMU Negeri 92 Jakarta. Jurnal Pilar Nusa Mandiri,Vol.XII, No. 1.

Patilima, H. (2015). Resiliensi anak usia dini. Bandung: Alfabeta.

Prihastuti. (2011). Profil resiliensi pendidik berdasarkan resilience quetient test, Jurnal Penelitian dan Evaluasi Pendidikan.

Poerwadarminta, W.J.S. (1995). Kamus umum bahasa indonesia. Jakarta: PT.Balai Pustaka
Purwanto. (2008). Metodologi penelitian kuantitatif. Yogyakarta: Pustaka Pelajar.

Putro, K.Z. (2017). "Memahami ciri dan tugas perkembangan masa remaja". Jurnal Aplikasi Ilmu-ilmu Agama, Vol 17, No1,25-32.

Ranty, D. (2017). Pengaruh resiliensi terhadap harga diri siswa korban perceraian orang tua kelas VIII SMPN 3 Cilacap. (Versi Elektronik). Jurnal Riset Mabasiswa Bimbingan dan Konseling, Vol 3, No 6.

Reivich, K. \& Shatte, A. (2002). The resilience factor: 7 essential skills for overcoming life's inevibale obstacles. New York: Broadway Books.

Resty, G.T. (2015). Pengaruh penerimaan diri terhadap harga diri remaja di Panti Asuhan Yatim Putri Aisyiah Yogyakarta. Skripsi (Tidak diterbitkan). Universitas Negeri Yogyakarta.

Roellyana, S \& Listiyandini, R.A. (2016). Peranan optimisme terhadap resiliensi pada mahasiswa tingkat akhir yang mengerjakan skripsi. Prosiding Konferensi Nasional Peneliti Muda Psikologi Indonesia, Vol. 1, No. 1, 29-37.

Rojas, L.F. (2015). Factors affecting academic resilience in middle school students: A case study. Gist Education and Learning Research Journal, 11(11), 63-78.

Rutter, M. (1993). Resilience: Some conceptual considerations. Journal of Adolescent Health, 14(8), 626-631.

Santrock, J.W. (2007). Psikologi perkembangan remaja. (Alih Bahasa) Edisi 11 Jilid 1. Jakarta: Erlangga. 
Santrock, J.W. (2007). Psikologi perkembangan remaja. (Alih Bahasa) Edisi 11 Jilid 2. Jakarta: Erlangga.

Santrock, J.W. (2012). Life-span development: (Alih Bahasa) Perkembangan masa bidup. Edisi 13 jilid 1. Jakarta: Erlangga.

Sarwono, S.W. (2012). Psikologi remaja: Definisi remaja. Jakarta: Raja Grafindo Persada.

Schultz, D. (1991).Psikologi pertumbuban. Yogyakarta: Kanisus.

Setiawati, F.A. (2017). Statistika terapan. Yogyakarta: Parama Publishing. Smith, A. (2013). Excellence in resilience

Sugiyono. (2012). Metode penelitian kuantitatif, kualitatif, dan red. Bandung: Alfabeta.

Tefera, B. \& Mulatie, M. ( 2014 ). Risks, protection factors and resilience among orphan and vulnerable Children ( OVC ) in Ethiopia: Implications for intervention. International Journal of Psychology and Counseling, Vol. 6(3), 27-31.

Theron, L,. Cockcroft, K, \& Wood, L. (2017). The resilience-enabling value of African folktales: The read-metoresilience intervention. School Psychology International 2017, Vol. 38(5) 491-506.

Utami, C.T \& Helmi, A.F. (2017). SelfEfficacy dan resiliensi: Sebuah tinjauan meta-analisis.(Versi Elektronik). Buletin Psikologi. Vol. 25, $54-65$.

Wang, L,. Tao, H, dkk. (2017 ). Influence ofsocial support and self-efficacy on resilience of early career registered nurses. Western Journal Of Nursing Research 